\title{
THE PLACE OF THE LIBRARY
}

Addressed to the Associated Friends, May I2, 1939

By Lane Cooper

$\mathbf{W}$

HEN we say 'the place' of the heart or head among the parts of the body, we mean also the function of the head or heart, what it does in its place. And similarly if we speak of the place of Rutgers Library, as it were the head, or the place of Kirkpatrick Chapel, the heart, we also mean the function of the Library or Chapel in the University, what each does or ought to do in its place. The function of the Library, of course, means the function of the books that speak to us in such a place. Thus we come to the place of a speaker, which likewise involves his function; and by 'speaker' we clearly must mean the author of any discourse and of any book as well. Speakers, then, may and do speak of any one or more of three things, though in general they ought to limit themselves to one. A speaker may talk of himself; the duller and less well-prepared they are, the more they do it. Or he may talk of his audience to win or flatter it; most of ten that is morally worse than egocentric speaking. It is enough to say 'Our Father,' or 'Our Alma Mater,' 'hallowed be thy name,' or 'Friends, it is good for us to be here,' and then get on to Number three. For, thirdly, when the brief preliminaries are over, and the audience is quiet, the speaker should talk about his subject; he should not continue flattering the audience, or keep prating about Number one, or mixing Number one and Number three together-as 'the "Lusitania" and I,' 'I and the League of Nations,' 'I' and some sort of 'deal,' whether 'square' or new and raw and a crack-pot, jack-pot deal. Like Homer, he should talk of Number three, the War, or whatever his subject may be, the Battle of the Books perhaps, or their war against vulgarity and meanness, and should say as little as he can about himself. To-night when we have to do with libraries and books we should remember that the best books in a library are not about their authors, and do not flatter the reader, but keep the interest up on Number three. 
Under Number three there are four main things that a speaker may discuss, and of course all four are things that men discuss in books, and hence a library must contain some books about all four. A general library should not be lacking in books of any of the classes, four, that we here have in mind. It happens that all four subjects are mentioned in the right perspective in Psalm 8: 'O Lord, our Lord, ... when I consider thy Heavens, ... what is Man?... Thou hast made him a little lower than the Angels.' The four things, then, that books can deal with are God, man, spirits other than God and man, and, fourthly, the physical universe, the world, so called, of nature. The same four things are mentioned in a similar perspective by Hamlet in soliloquy, where Shakespeare makes him talk in Hamlet's talkative way about the starry heavens as a roof fretted with golden fire, of man as in action like an angel, and even of man as in apprehension like a god. We might go on to Dante, Milton, and Wordsworth, and to writers of our day who may seem to have a different perspective, but the main result would be the same. A man or book may talk more of God, or more of man, or more of spirits good and bad, or more about the heavens and the universe (including animated nature), but man cannot talk of any other thing, for there is nothing else to talk about; so that even if a writer tried to prove that none of them existed - no God, no man, no spirits whatsoever, and no nature, the subjects he could talk about would still be four. It may be thought that books and speakers of late have tended to neglect the most important of the four. Ruskin said of his own generation, not so long ago, that there never had been an age so fitly described as his age was by the Biblical phrase, 'without God in the world.' What would Ruskin say of our age if he were writing now? Yet God turns up, like his angel of death, in places where men least expect him. As the rabble-rouser at Cologne let slip before he knew it the statement that he was the Moses of his people, so even the same loud speaker names his god not Woden or Thor, but Providence, while other neo-pagans call on God to punish England. Nor is God utterly forgotten in the 'concentration-camps.' And, thanks to Pastor Niemöller in a 'concentration-camp,' many people everywhere are thinking more of Somebody they had for a while lost sight of. 
Again, it may be thought that recent books have little to say of angels good or bad; that books are nowadays more often concerned with man, and that the most important books are those that deal with matter, Number four, and not with spirit, which, that is, spirit, really includes the other three, God, man, and other spiritual beings. But the truth is that, to publishers, and hence no doubt to readers, the Bible, our light from Palestine, is the most important book, most often printed and reissued in numberless editions everywhere in every tongue; and that recent books on physical science have had very brief lives indeed. In their constant warfare they dislodge one another so fast that the layman hardly has time to grasp and entertain one modern concept of the universe before he is called upon to give that up and take another. Is physical light a vibratory motion in a medium or an emanation? The question is in hot debate, or was when last we heard. Meanwhile various men of science, as we call them, are returning to the concept of a spiritual First Cause of all things; sometimes their conception reminds us more of Nous or Mind as Anaxagoras conceived of that; sometimes even, the Intelligence they refer to may remind us of 'the Love that moves the sun and all the stars'; at length some physicist may bethink himself of the beginnings mentioned in the Old Testament and the New: In the beginning God created the heaven and the earth; In the beginning was the Word, the Logos, and the Word was God. We may venture to think that in a hundred or a thousand years, when men look back upon what was read and held in memory in this our year of nineteen thirty-nine, they will note that, as in eighteen thirty-nine, readers saw things in just the same perspective as did the author of Psalm 8. The Psalm is right, and has impressed itself on the collective memory of civilized mankind. What is man? Not much perhaps in comparison with the starry heavens, yet, after all, not far below the angels.

For look! He can entertain them unawares, and afterwards draw and picture them, and repeat their song. His apprehension is so far like that of God that he can feel after Him, and thus apprehend $\mathrm{Him}$, and is ever learning more and more about His universe and universal reason. The books about God, man, the angels, the heavens above and earth beneath, are all of 
them books of men, books written by men, and printed by men, and read by men; which means mankind, and that means women too, though by your smiling you might seem to hint I had forgotten them. They too have written and read and printed books. We do believe that the best of books proceed from men and women who have their inspiration from above, and know it, but the fact remains that books and libraries are the work of man, and, in the fourfold differentiation we have noted, clearly belong among things human. That the heavens declare the glory of God is an utterance in the tongues of men, not far below the tongues of angels.

And thus we have begun to place the library and to think about its function. A library is a place where human books are stored and used, and books are, on earth, and next to churches, the most important and lasting product of mankind. Nay, so far as they preserve eternal words, they are, like churches, the treasuries of that which will outlast all else. To take an instance from the Classics, the Iliad and Odyssey are still on earth when all the rest of the Aegean culture which they represent is virtually gone, or can be reconstructed in imagination only with their help. To take a nobler instance, we have it on authority that words outlast the universe of matter: Heaven and earth shall pass away, says the eternal Poet, "but my words shall not pass away.' As for any book that we value, it has a value outlasting the life of the individual man himself. Says Milton: 'For books are not absolutely dead things, but do contain a potency of life in them to be as active as that soul was whose progeny they are; nay, they do preserve as in a vial the purest efficacy and extraction of that living intellect that bred them.' And again, Milton says: 'As good almost kill a man as kill a good book; who kills a man kills a reasonable creature, God's image, but he who destroys a good book kills reason itself, kills the image of God, as it were, in the eye. Many a man lives a burden to the earth, but a good book is the precious life-blood of a master-spirit, embalmed and treasured up on purpose to a life beyond life.'

It is the function, then, of libraries and books to keep what we call civilization alive on earth while individual men are dying. Doubtless books do more than that, and if the Library is the head, it helps the heart, the Chapel, of the University, pre- 
pare us also for a life above the mortal life of man. But here and now we are dealing with the Library as that intellectual organ of the University which we have called the head, and must consider its usual relation to the whole. The Library is in so far like the Chapel that it serves the whole, and not some part or parts thereof. Each several part of any organism does indeed minister to the welfare of the whole, but not all of them quite as the head and heart do. The department of history or physics works for the good of the whole by functioning well in the study and teaching of history or physics. We need not labor the point. The Library, like the Chapel, has more general functions. And as the Chapel has the highest function, and the great toe of athletics the lowest, so the Library has the one next to the highest, and, it may be said, the broadest. Its function is identical, almost, with the function of the University in the State; while the function of the Chapel is a function which the Chapel shares with another institution in the State, that is, the Church.

Then what is the main function of the University, that function which the function of the Library so nearly equals? Obviously the business of the University is the advancement of learning in learning's two main branches, the discipline or science, in its many subdivisions, which we may call the science of the spirit, and that other branch, with many subdivisions, which we may call the science of matter. Let others discuss the advancement of physical science; important as it is, its importance and total result in our time are overrated, especially by those who lack a thorough scholarly and scientific training. Of both branches we now have merely to note that the only real advertisement of a university is the well-trained men it sends out into the world, or retains within its walls; and they advertise the institution by quietly doing their appointed work, contemplative or active, throughout their life. They let their light shine; they do not bawl about their light, which after all is not their own, but, as Dante would say, Another's. Those men whom the institution retains in its own service best advertise it by publishing the fruit of their investigations. We may add that, before the days of noisy university and college advertisement, in the horse-and-buggy days of Rutgers College, she sent out the two most eminent 
men, respectively in humane letters and physical science that our United States has yet to boast of, Albert S. Cook in the humanities and George W. Hill in the realm of astrophysics. Now that Rutgers University has a Press, a University Press in which the Library must have a deep concern, it might be well to make sure on the spot that certain works of men like these shall ever be kept in publication for the benefit of posterity; and I will mention in particular Cook's wonderful address, The Artistic Ordering of Life, which he delivered to a Rutgers audience some forty years ago, and his fine volume, $T$ be Higher Study of English, which is likewise out of print. The Rutgers University Press might well undertake a collective edition of his works to match the like edition of the works of Hill, in which, unfortunately, his Alma Mater did not have a hand.

On the side of the humanities, it is the business of a university to send out leaders of the State, doctors, jurists, teachers, politicians of the better sort-above all, scholars. Thereby we lovers of the Library mean productive scholars in the stricter sense, but we also mean that men who go out from a university in to the learned professions should go out with an abiding interest in studies and the method of study. From the university the scientific men as they are called are likely to go out with a method they have learned in laboratories, and, we hope, from mathematics; though if they are really to be good in their own realm, they ought to know enough about the history of physical science and the history of the special branch they cultivate; and for that historical perspective which American men of science sorely need, they ought betimes to cultivate an acquaintance with the Library. When they do so, they are scholars. And the other scholars too will benefit by knowing more than most of them do about the history of science-which history should teach them that the history of scholarship and science is all one, and that the method of the scientist so-called and the so-called scholar must in essence be identical; for scholarly and scientific method are determined by the nature of the human mind, and by one universal logic which can never vary.

All the same, a library is the place of scholars. If you are looking for a special kind of game-bird, English snipe or woodcock, or for grouse or pheasants, you go to the haunt where 
each is commonly to be found. And if you are hunting for scholars, go to a library, and there they are.

What is a scholar, this creature which the college and its library produce? The great geographer Ratzel, most eminent in his time and even now, this great man Ratzel used to say that any one who went out of his own door, and used his eyes, and saw what actually was to be seen, was a geographer. And so we might say that any one who goes into a library, opens a good book, and sees what actually is there, is a scholar. You may object, and say that any one who is going to read a book, and to see the truth or falsehood in it needs to bring along some special training and perhaps much knowledge. Let the book be the long epic poem of Milton. Doesn't one need some knowledge of Latin, of the Bible, and of classical mythology, if one is going to understand the Paradise Lost of Milton? Well, we may grant that it will help the reader of Milton if he knows the Bible, the most helpful of all books always and to all, and will do no harm to know a bit of Latin and some classical mythology. But we may doubt if Latin and mythology were what Milton had in mind when he said that he desired 'fit audience ... though few.' He clearly shows that first of all he wishes for readers with an 'upright heart and pure.' Such readers are likely to have read the Bible. But the truth is that many a reader of Paradise Lost has failed, as Byron failed, to do it justice because, along with Byron, his heart was not too pure and upright. The poem really is intelligible to good people if they will only read it aloud. Milton habitually adds light enough to his allusions to help the reader on. No, as Saint Paul shows, there is something more important than great knowledge if you wish to be a scholar. Paul himself had too much knowledge of various sorts, and knew too many languages, surely at least three, to say that such things have no value, given something else. The tongues of men and of angels, and indeed all knowledge, have no value, he says, without charity or love. No doubt that love must mean the love of God, of man, of ministers of grace as Hamlet calls them, and of the lovely universe as a geographer named Milton saw it, the fourfold love implicit in Psalm 8. And no doubt Saint Paul would say the same of hope and faith, which latter we may call imagination. Without hope you cannot be a 
scholar, and without imagination you cannot be anything, no matter how many languages you pretend to read, or how many bare facts you have stored up in a godless, loveless, hopeless memory. If you have these gifts, imagination, hope, and loveand they are said to be had for the asking if only you keep at it - you are likely, if you choose the life of a scholar, to acquire a knowledge of the languages and to store your treasure-house, your memory, with a great deal of other knowledge, or at all events of such other knowledge as you need; a man can hardly take up the life of a teacher, and then not decently obey the rules of the game, not study enough to publish. Apart from school, a man may be well-read in many books, as Theodore Roosevelt was, and be a scholar; or well-read through intensive knowledge of a few, the best, as Lincoln was, and be perhaps a better scholar.

We might here say somewhat more of research, and might add that no essential difference exists between discovering something new, that nobody before has known, or that everybody has forgotten, and learning something that is new to you but not to others of your generation. Here pupil and teacher meet.

In a well-conducted university the pupils necessarily must learn many things that their teachers already know, but the more the process is made to be like fresh discovery- the more it is fresh discovery-the better the result alike for teacher and pupil as they share it. In the circle of humanities, a sharpeyed pupil with an upright heart and pure will on reflection often see a meaning in the work of Sophocles or Milton, or a true relation in their thoughts, that has escaped the notice of good modern editors. Meanwhile, the teachers cannot lead in the advance of learning unless they give some of their leisure to research in the stricter sense. A leader of young scholars must share in the advancement of learning by doing something for the commonwealth of scholars throughout their nation and throughout the world. It is sometimes thought by persons who know little about scholarship that great scholars are not always good teachers. I can only say that for a period of forty years I have tried to find an instance of a truly great scholar who has shown himself incapable of teaching, even of teaching little children, and for forty years this animal has eluded my 
view. You can find pedants lacking in sympathy and perspective, but we do not call them scholars, for good scholars are not pedants, and we do not call a man a scholar if he lacks sympathy or perspective. The processes of learning and teaching are, in fact, so closely linked and intertwined that it is impossible to untie them. The notion that Tom, Dick, and Harry have concerning poets is probably not very much like any real poet; and the same no doubt is true of vulgar notions about scholars.

We have briefly touched on some positive functions of a library in an institution of learning, where teachers gladly learn and gladly teach. A library has also negative functions; not only fights for some things, but fights against some others. A well-weeded library, well-watched, protects the reader against folly and indecency. Doubtless we tend to go far enough in weeding out indecent books. We certainly could go farther towards eliminating foolish and inferior books; inferior books about the poets, for example, and inferior editions of their works. And a library well-rounded is a foe to godlessness and inhumanity. Along with the godlessness and vulgarity of harmful books goes their tendency to take human life, and show it, at its worst, and not at its best as something good and beautiful.

One other function of this negative and protective sort may now be mentioned. It relates to the monstrous thing we call athletics, once imported into our American schools and colleges from England-from Oxford and from Cambridge. But for its source it might have been saddled on our fire-departments or police-departments, where perhaps ideally it belongs. It did not come from the universities of Ireland or of Scotland, whence some of the best elements in American education are derived. It did not come from the great universities and training-schools of Continental Europe, which have served their nations and all other nations well without it. It did not come from Italy and Bologna, nor yet from the Mediaeval schools and monastic institutions that preceded the Italian universities. There was nothing like it in the Hebrew education that has given us the greatest bulwark of good taste and culture called the Bible. Nor did athletics as we know them come from Greece; the difference between what Plato called gymnastic, 
which he put almost on a par with music as a civilizing force, the difference between the life of his Academy on the physical side and our intercollegiate sports to-day, is quite abysmal. And the saddest aspect of our system is the childish interest that older people take in these athletic competitions as compared with any general interest they show in the real functions of a college, those functions which are represented by the Library, and typified by the Chapel. It is natural for the young to be fond of victory in physical encounter. 'When I became a man,' says Paul, 'I put away childish things.'

The evil got its foothold in the time of so-called educational leaders who are long since dead. They were afraid to curb the evil in its onset, or they did not have the foresight needed for the guidance of the institutions which they thought they led. It does not take much courage now, nor insight, to speak about the evil, and to tell the truth about it, since the argument most often urged in favor of athletic contests between universities grows annually weaker. Athletic victories no longer advertise a school, since nobody remembers who beat whom, while Southern Methodists and Texas Christians (save the mark!) nevertheless beat older institutions that should be, as indeed a few still are, somewhat stronger in the head and heart than the aforesaid Methodists and Christians. We hope it can be truly said of Rutgers University that she is less infected with the virus than are other institutions of the eldest type. But again, from time to time we hear it said that the best athletic trainers benefit their pupils more than do the teachers on the faculty. If it were so, it would be a dreadful condemnation of our universities and our educational system as a whole.

Of all the evils appertaining to athletics and our educational system, those connected with the game called football are the worst. The commercializing of the game; its lack of amateur ideals; drinking; gambling; the supposed necessity of having a team that will earn six per cent or more for the Italian who advanced the money for the 'stadium' or 'coliseum'; such things we mention as we pass to a few words on the game itself in relation to the players. It spoils the education proper of nearly all the men who play it. For their bodies, it most often injures their joints, especially the knee, and their heads - that part for which a university exists. The knee-joint and the head very 
seldom permanently recover, perhaps never fully do so, from a real hurt. The injury of ten lurks until the man, having passed the acme of his physical strength, is at the acme of his business or professional life; then lays him low. The injury to his knee comes back to lame him; the injury to his head cuts short his business career. There are also heart-strains, kidney-strains, and lung-strains; every player on the team, so the players say themselves, is nursing a hurt. Broken bones and injured muscles heal well enough in a young man, save for the heart. At the age when he has most to live for, and most depending on him, the heart-strain kills him in his tracks. Where is the evidence? Read the daily papers. Why medical men do not openly condemn the game of football wholesale is very strange; parents do in private talk about the bills for treatment. Perhaps the doctors too, like far too many others, look to a university, not for what a university should produce, trained heads as leaders in the State, trained hearts in the clergy, but for a weekly show on the order of a gladiatorial contest or a bullfight.

And what has the Library to do with this, this octopus which seems to have a strangle-hold upon the neck of American education? Athletes pass and die, the Library goes on, so to speak, for ever; there it is, a salutary force, quiet, without advertisement, unceasingly working against the evils that beset our education; yet evils that are, after all, and taken singly, of but a temporary nature and without a lasting cohesion.

But what of the greatest evil of all, not for the university alone, but for the State? What of war, and what have libraries to do in counteracting that? We hear a statement, have heard it so often repeated that it now sounds vulgar; we hear it stated that another war, vaster than the one that went before it, which was the greatest war to date, will shortly put an end to modern culture. Has anybody really thought this matter out? The last war certainly did damage to the library at Louvain, but certainly did not kill religion at Louvain, intensified it, rather, and the outward damage has been repaired. And the last general war was not relatively so disturbing as were the Napoleonic wars, which upset Europe off and on from I798 till Waterloo well-nigh a generation later. Let us suppose, however, that alien bombers shortly bombed the Harvard Library, or the library of Yale, but did not damage both, or 
ruined both of these, but did not damage Brown, or even wrecked the libraries in New York or Washington, but not the aforesaid libraries of Harvard, Yale, and Brown. Or suppose that all the libraries on our Atlantic coast were wrecked, or most of them, while the great universities of the Middle West and California went unscathed? Would civilization in America then be ruined? While we talk about the place of libraries, think how they are placed in our own country. It would take more system than the Continental nations yet possess to ruin all each other's libraries, and after that the libraries at Dublin, Glasgow, Edinburgh, and London, at Oxford, Cambridge, Manchester, and other British universities, and then come over here to bomb all other libraries from Maine to Oregon and from Los Angeles to Durham and Chapel Hill. With the newer means of duplication, almost any library to-day can have a copy of any book or writing in the world. A moderate college library to-day is richer in books than most of the great libraries in the day of Waterloo. Think merely of the difference between our Rutgers Library now and the old collection in Kirkpatrick Chapel only forty years ago. The preservation of the library at Urbana, Illinois, if only that were saved out of a universal ruin, would save modern culture, if some spiritual gifts were saved as well. The preservation of our Rutgers Library would do as much under the same conditions. These conditions count. The Library could be reproduced a hundred or a thousand times, if need be, by our modern methods. But photostats and photographs are not the sole condition. Civilization or salvation came from Palestine, and to some extent from Greece; it was spread by Rome, and has been spread by modern nations, France, Italy, and Spain, and Germany too among them, by Great Britain above all. The civilizing, saving thing that came from Palestine was a clear belief in God the Father of all men, set forth and spread by Christianity. Loud speakers of the eighteenth century in France essayed to do away with God and Christianity, and failed; the eighteenth century passed away, but the words of life and light from Palestine will never pass away. Sol justitiae et occidentem illustra. Sun of righteousness, still shining from the East, shine also upon our West and this our Alma Mater with its books and students. 